\title{
Population Parameters Of Distichodus Rostratus (Gunther, 1864) From The Hydrosystem Located Between The Hydroelectric Dams Of Kossou And Taabo (Bandama River; Côte d'Ivoire)
}

\author{
Berte Siaka, PhD Maitre Assistant \\ Laboratoire d'Hydrobiologie, UFR Biosciences, \\ Université Félix Houphouët-Boigny, Abidjan, Côte d'Ivoire. \\ Kone Naminata, PhD Assistant \\ Département de Sciences et Technologie, \\ Ecole Normale Supérieure (ENS) d'Abidjan, Abidjan, Côte d'Ivoire \\ Ouattara Nahoua Issa, PhD Maitre Conférence \\ Kouamelan Essetchi Paul, PhD Professeur \\ N'douba Valentin, PhD Professeur \\ Laboratoire d'Hydrobiologie, UFR Biosciences, \\ Université Félix Houphouët-Boigny, Abidjan, Côte d'Ivoire
}

doi: 10.19044/esj.2016.v12n24p157 URL:http://dx.doi.org/10.19044/esj.2016.v12n24p157

\begin{abstract}
Growth and mortality parameters, exploitation rates and annual recruitment patterns were estimated using FiSAT program from monthly length-frequency and weight samples of Distichodus rostratus captured from the hydrosystem located between the hydroelectric dams of Kossou and Taabo (Bandama River). Samples were collected from July 2004 to June 2005. The aim was to estimate growth parameters, mortality rates, exploitation rate and recruitment pattern of $D$. rostratus for sustainable management. The von Bertalanffy growth parameters asymptotic length L $\infty$ (cm) and growth constant K (per year) were 69.30 and 0.27 respectively. Goodness of fit $(\mathrm{Rn})$ was 0.27 . The growth performance index $\left(\varphi^{\prime}\right)$ value was 3.11. Age at maturity was estimated at 2.87 years for males and 3.78 years for females. The maximum age estimated was 11.095 years. The annual rate of fishing mortality $(\mathrm{F}=0.10)$ was low compared to the relatively high natural mortality $(M=0.60)$. The exploitation rate $(E=0.14)$ shows that the species was not over-exploited in the Bandama River.
\end{abstract}

Keywords: Growth and age, mortality, exploitation rate, Distichodus rostratus, Bandama River 


\section{Introduction}

Distichodus is a genus of Distichodontidae, a family of the grass eater endemic to Africa. It is a demersal potamodrous freshwater fish distributed throughout West Africa. Yet, it is absent in coastal basins comprised between Southern Gambia and the Sassandra (Gosse et al., 2003). With approximately 7 genera, this family is represented by 18 species in West Africa. In the Bandama River, three species of Distichodontidae are known: Nannocharax fasciatus, Noelebies unifasciatus and Distichodus rostratus (Aboua et al., 2010). Distichodus rostratus is a commercially important fish for the inhabitants of Côte d'Ivoire.

Into man-made lakes and between the hydroelectric dams of Kossou and Taabo of Bandama River, the fishing pressure is increasing due to increase in the number of artisan fishing crafts. On the other hand, information on fishing pressure and stock position of important commercial fishes are limited.

Demographic modelling is a popular approach because it provides the best available description of the population being studied given several life history parameters. Demographic modelling therefore provides a compromise between simple life history tables and more detailed stock assessment models (Booth et al., 2011).

The knowledge about species biology and ecology, especially regarding growth information, is essential to promote its exploitation in a sustainable way, avoiding depletion of stocks. Developing methods to determine life-history parameters of $D$. rostratus is the first step in understanding their life strategies and in making sound policy decisions. The objective of this study was to estimate the population parameters and exploitation of $D$. rostratus in the Bandama River.

\section{Materials And Methods \\ Study area}

The Bandama River has a main channel stretching over a distance of $1050 \mathrm{~km}$ and an area of 97,500 $\mathrm{km}^{2}$ between its source in Sirasso and its mouth in Grand-Lahou (Girard et al., 1971). The Marahoue River $(550 \mathrm{~km}$ length) and the N'Zi River (725 km length) are the only tributaries of the Bandama River. On its course are the two hydroelectric dams namely Kossou and Taabo man-made lakes (Lévêque et al., 1983). The climate of the hydrosystem is an equatorial transition zone with two rainy seasons (April-June and September-November) and two dry seasons (July-August and December-March) (Iltis \& Lévêque, 1982).

The main fishing areas of $D$. rostratus in the Bandama River are located in the hydrosystem between the hydroelectric dams of Kossou and Taabo. 


\section{Fish sampling and data collection}

Specimens were collected monthly from commercial fishery landing between July 2004 to June 2005. A total number of 1643 individuals of $D$. rostratus for both sexes were captured using two gears: gill-nets and hoopnets. Determination of fish was done by using the key Gosse et al. (2003). Fish were measured for standard length (SL) to the nearest $1 \mathrm{~mm}$. As to weighing, a precision balance with $0.1 \mathrm{~g}$ accuracy was used. Fish specimens were grouped into classes of 2 centimeters intervals. Data analyses were based on FISAT II (Gayanilo et al., 2005). The ELEFAN I program in FISAT II was applied to estimate the growth parameters $L_{\infty}$ and K. Growth relations were also examined according to growth equations. For age to size relation the Von Bertalanffy growth equation was used:

$\mathrm{L}_{\mathrm{t}}=\mathrm{L}_{\infty}\left(1-\mathrm{e}^{-\mathrm{K}\left(\mathrm{t}-\mathrm{t}_{0}\right)}\right)$

Where : $\mathrm{L}_{\mathrm{t}}=$ Length of fish at age $\mathrm{t}$;

$\mathrm{L}_{\infty}=$ Asymptotic length;

$\mathrm{K}=$ Von Bertalanffy growth coefficient;

$\mathrm{t}=$ Theoretical age of fish at which the length is zero.

The $t_{0}$ value estimated using the empirical equation Pauly (1979):

$\log _{10}\left(-\mathrm{t}_{0}\right)=-0.392-0.275 \log _{10} \mathrm{~L} \infty-1.038 \log _{10} \mathrm{~K}$

An index of goodness of fit $(\mathrm{Rn})$ was determined by automatic computer (Gayanilo et al., 2002).

The growth performance index of $D$. rostratus population in terms of length-growth was calculated using FISAT II according to the equation (Sparre \& Venema, 1998)

$$
\varphi^{\prime}=\log _{10} \mathrm{~K}+2 \log _{10} \mathrm{~L}_{\infty}
$$

Where : $\mathrm{L}_{\infty}=$ Asymptotic length;

$\mathrm{K}=$ Growth coefficient

Estimation of total mortality ( $\mathrm{Z}$ ) was derived from the linearized length-converted catch curve produced by the ELEFAN II routine. empirical

Natural mortality rate (M) was derived through using Pauly's (1980)

$$
\log _{10} M=-0.0066-0.279 \log _{10} L_{\infty}+0.65443 \log _{10} K+0.4634 \log _{10} T
$$

Fishing mortality coefficient (F) was estimated from Gulland (1971) equation: $\mathrm{F}=\mathrm{Z}-\mathrm{M}$

The exploitation rate (E) was obtained by Gulland (1971) equation: $\mathrm{E}=\frac{\mathrm{F}}{\mathrm{Z}}=\frac{\mathrm{F}}{(\mathrm{F}+\mathrm{M})}$

The exploitation rate indicates whether the stock is lightly $(\mathrm{E}<0.5)$ or strongly $(E>0.5)$ exploited, based on the assumption that the fish are optimally exploited when $\mathrm{F}=\mathrm{M}$ or $\mathrm{E}=0.5$. 
Estimates of length-at-first-capture $\left(\mathrm{L}_{50}\right)$ were derived from probabilities of capture generated from the catch curve analysis.

The annual recruitment pattern was produced following Moreau \& Cuende (1991), through reverse projection of the entire length-frequency data onto the time axis. The data were fitted onto an arbitrary one-year time scale. This annual recruitment pattern was then fitted with Gaussian distributions using the maximum likelihood approach through the NORMSEP program incorporated into FiSAT.

Age at maturity $\left(\mathrm{t}_{\mathrm{m}}\right)$ was calculated according Booth et al. (2011) $\mathrm{t}_{\mathrm{m}}=\mathrm{t}_{0}-\frac{1}{\mathrm{~K}} \ln \left(1-\frac{\mathrm{Ls}_{50}}{\mathrm{~L} \infty}\right)$

Where : $\mathrm{Ls}_{50}=$ Length at maturity obtained from Berté et al. (2008) $\mathrm{L}_{\infty}=$ Asymptotic length; $\mathrm{K}=$ Von Bertalanffy growth coefficient; $\mathrm{t}_{0}=$ Theoretical age of fish at which the length is zero.

The potential life span (Tmax) was estimated from the formula (Pauly, 1983) $\operatorname{Tmax}=\frac{3}{\mathrm{~K}}+\mathrm{t}_{0}$

\section{Results}

\section{Growth parameters}

The estimated values of growth parameters for Distichodus rostratus from the hydrosystem between man-made Lake Kossou-Taabo (Table 1) indicated asymptotic length $\left(\mathrm{L}_{\infty}\right)$ of $69.30 \mathrm{~cm}$ and growth coefficient $(\mathrm{K})$ value of 0.27 per year. Hypothetical age $\left(\mathrm{t}_{0}\right)$ was estimated as -0.3079 year, which gave the Von Bertalanffy growth equation (Fig. 1) for this species as: $\mathrm{Lt}=69.30$ (1-exp [-0.27( $\mathrm{t}+0.3079)])$.

Table 1: Growth parameters of Distichodus rostratus between two man-made Lake (Kossou and Taabo)

\begin{tabular}{cc}
\hline Parameters & Values \\
\hline Asymptotic length $\left(\mathrm{L}_{\infty}\right)$ & $69.30 \mathrm{~cm}$ \\
Growth coefficient $(\mathrm{K})$ & 0.27 year $^{-1}$ \\
Growth performance index $\left(\varphi{ }^{\prime}\right)$ & 3.11 \\
Goodness of fit index $(\mathrm{Rn})$ & 0.27 \\
Hypothetical age $\left(\mathrm{t}_{0}\right)$ & -0.3079 year \\
Longevity (Tmax) & 11.095 years $^{-1}$ \\
\hline Total mortality $(\mathrm{Z})$ & 0.70 year $^{-1}$ \\
Natural mortality $(\mathrm{M})$ & 0.6 year $^{-1}$ \\
Fishing mortality $(\mathrm{F})$ & 0.10 year $^{-1}$ \\
Exploitation rate $(\mathrm{E})$ & 0.14 \\
\hline
\end{tabular}




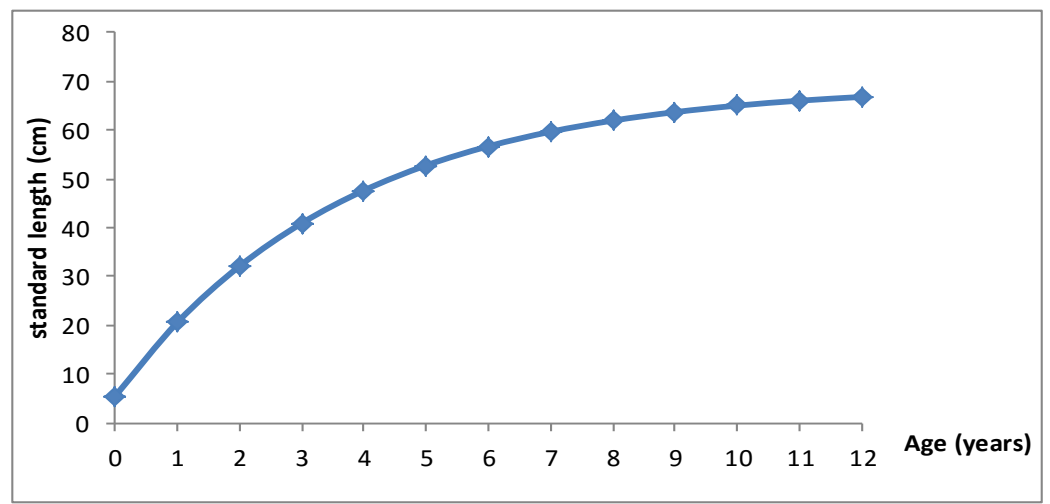

Figure 1: Von Bertalanffy growth curve for Distichodus rostratus in Bandama River

The original and restructured length frequency data superimposed with estimated growth curve are shown respectively in figure 2 and figure 3. The goodness of fit ( $\mathrm{Rn})$ was 0.27 by automatic computer generation. The growth performance index was estimated as $\varphi^{\prime}=3.11$. D. rostratus had a long life span of 11.095 year. Estimated male and female age at maturity (tm) was 2.83 years and 3.78 years respectively.

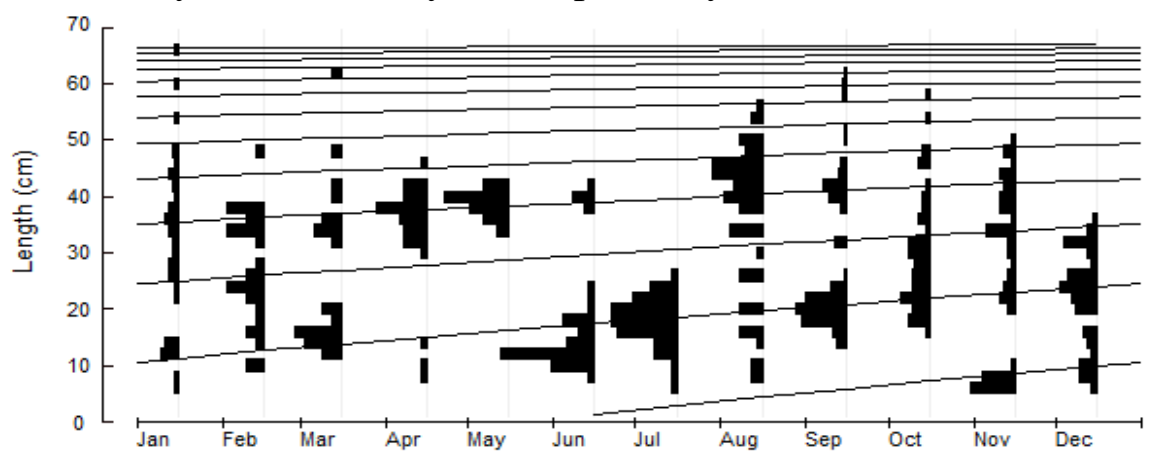

Figure 2: Growth curve of Distichodus rostratus with normal length-frequency histograms $(\mathrm{L} \infty=69.30 \mathrm{~cm} \mathrm{SL}, \mathrm{K}=0.27$ year- 1$)$

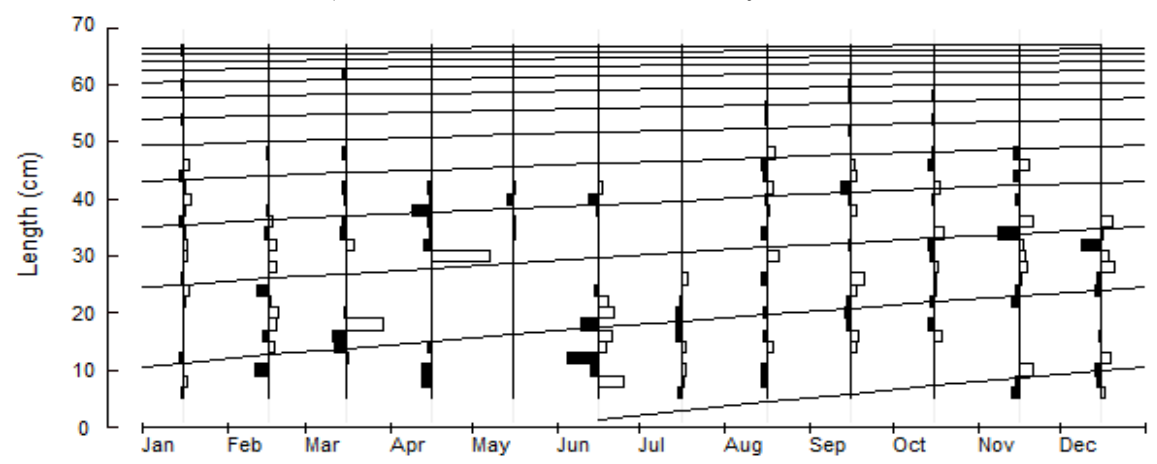

Figure 3: Growth curve of Distichodus rostratus with restructured length-frequency histograms. The black bars are positive values of length-frequency and the white bars are negative values. 


\section{Instantaneous mortality coefficients and exploitation rates}

The instantaneous mortality coefficients and exploitation rates for Distichodus rostratus are shown in figure 4 . The total mortality coefficient (Z) was estimated from the length of converted catch curve as 0.70 per year. The natural mortality (M) was estimated from Paula's (1980) empirical formula was 0.6 year $^{-1}$. The instantaneous rate of fishing mortality (F) was estimated to be 0.10 year $^{-1}$. The exploitation rate was estimated as $\mathrm{E}=0.14$.

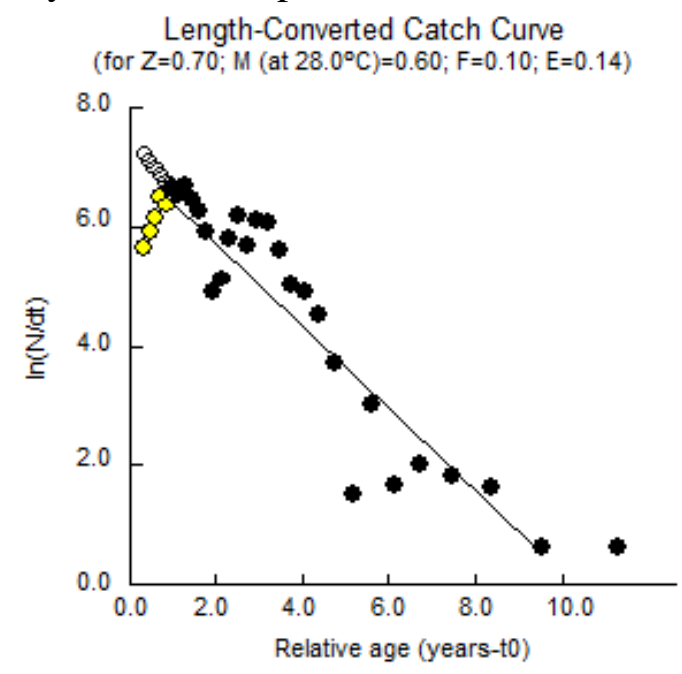

Figure 4: Length-converted catch curve of Distichodus rostratus

Dark circles in the figure represent the points used in calculating (Z) through least squares regression lines. The grey circles represent frequencies of fishes either not fully recruited or approaching $(\mathrm{L} \infty)$, and hence discarded from the calculation. The expected frequencies of not fully recruited fishes are added as blank circles.

\section{Lengths at first capture and recruitment patterns}

The length-at-first capture $\left(\mathrm{L}_{50}\right.$ or $\left.\mathrm{L}_{\mathrm{c}}\right)$ was $10.32 \mathrm{~cm}$. The estimated lengths at which $25 \%\left(\mathrm{~L}_{25}\right)$ and $75 \%\left(\mathrm{~L}_{75}\right)$ of the fish entering the gear are retained were $7.08 \mathrm{~cm}$ and $13.52 \mathrm{~cm}$ respectively (Fig. 5). 


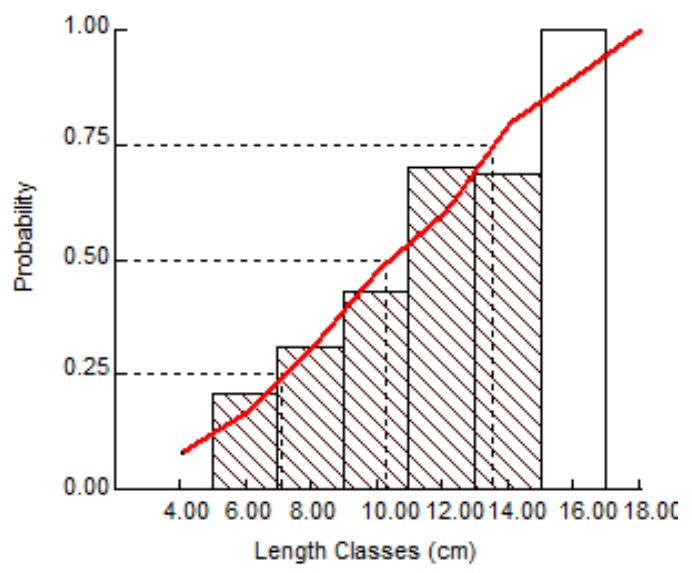

Figure 5: Probability of capture analysis for Distichodus rostratus $\left(\mathrm{L}_{50}\right.$ or $\mathrm{Lc}=10.32 \mathrm{~cm}$; $\left.\mathrm{L}_{25}=7.08 \mathrm{~cm} ; \mathrm{L}_{75}=13.52 \mathrm{~cm}\right)$.

The recruitment patterns showed one annual pulse of Distichodus rostratus. The model of recruitment of $D$ rostratus between two man-made Lake (Kossou and Taabo) is continual throughout the year (Fig. 6).

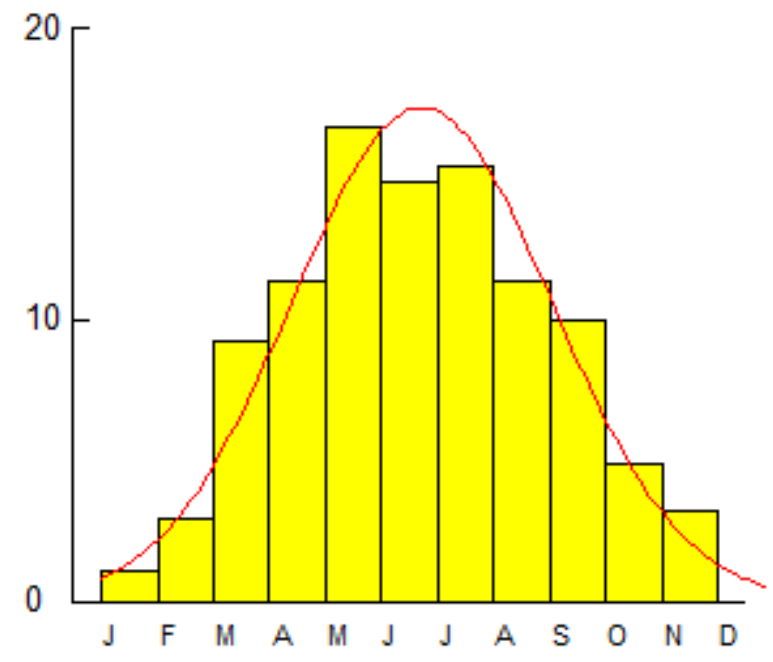

Figure 6: Recruitment pattern of Distichodus rostratus between two man-made Lake (Kossou and Taabo)

\section{Discussion}

Abowei (2010) estimated infinity length and growth performance index of Distichodus rostratus $55 \mathrm{~cm}$ and 2.87 from Num River. Moreau et al. (1995) estimated L $\infty$ and ö respectively $29 \mathrm{~cm}$ and 2.84 in dam of Guiers. 
L $\infty$ and ö estimated respectively $105.61 \mathrm{~cm}$ and 3.70 in Niger-Bénoué (De Merona et al., 1988).

The growth parameters estimated from this study shows also that $D$. rostratus in Bandama River presents a K estimated at 0.27 per year. Abowei (2010) reported the same values of growth pattern ( 0.27 per year) in Num River. Whereas this observation is differed than the findings of Moreau et al. (1995) and De Merona et al. (1988) respectively 0.83 and 0.22 per year.

Several authors have reported the estimated growth parameters can present inter and intra specific variations (Balon, 1971; King, 1991; Tah et al., 2010; Koné et al., 2014). Adams (1980) attributed the differences between recorded $\mathrm{L} \infty$ and $\mathrm{K}$ are influenced by environmental conditions, population size and frequency of species considering their habitat and according to natural selection, appear different adaptation pattern during their life.

The values of the hypothetical age at zero length $\left(\mathrm{t}_{0}\right)$ obtained in our study as -0.31 for this species. Overall study noted negative values for $D$. rostratus. Furthermore, this observation is lower than those observed by other authors in Niger-Bénoué (-0.48), Num River (-0.46) and Lake of Guiers (-0.71) (De Merona et al., 1988; Moreau et al., 1995; Abowei, 2010). King (2007) explained with negative $t_{0}$ values, juveniles grew more quickly than the predicted growth curve for adults and with positive $t_{0}$ values, juveniles grew more slowly.

Regarding to Tmax (Pauly, 1983), maximum age for this species was found to be 11.095 year. Nevertheless, the longevity value of $D$. rostratus was 13.2163 in Niger-Bénoué (), 6 in Num River and 2.904 in Lake of Guiers (De Merona et al., 1988; Moreau et al., 1995; Abowei, 2010).

According to Berté et al. (2008), the length of first maturity of $D$. rostratus in Bandama River was $39.6 \mathrm{~cm}$ SL for males and $46.3 \mathrm{~cm}$ SL for females. In this work, higher age at maturity (tm) values were reported for female 3.78 years. An estimate of tm for male was 2.83 years.

Although tm might differ between sexes in the present work, we found difference in the tm/Tmax ratio between males and females. The dimensionless tm/Tmax ratio shows that male mature very early, at around 1/4 of Tmax, within their lifespans. In contrast, female mature later, close to 1/3 of their Tmax. These values represent the proportion of time and growth that occurs before the onset of maturation, prior to the energy investment adults allocate to reproduction (Frisk et al., 2001). In general, the onset of maturity may depend mainly on age for short-lived species that mature early, and mainly on size for their longer-lived, late-maturing counterparts, with developmental or genetic constraints more evident in longer lived species (Archibald et al., 1983; Roff, 1983). 
The instantaneous rates of total mortality (Z), estimated here as 0.7 year $^{-1}$ was outside the range of 1.5 - 1.63 year $^{-1}$ estimated by Moreau et al. (1995) and Abowei (2010). D. rostratus was long lived in Bandama River than Num River and Lake of Guiers. Indeed, the short mortality rate is usually imperative as longer lived.

The M obtained by the Pauly's empirical formula was 0.60 year $^{-1}$ while $\mathrm{F}$ was 0.10 year $^{-1}$. The value of $\mathrm{M}$ in this study was lower than those observed by Moreau et al. (1995) in Lake of Guiers and Abowei (2010) in Num River, respectively 1.6 year $^{-1}$ and 0.97 year $^{-1}$. The estimated $F$ in this study is close to 0.5 year $^{-1}$ obtained in Num River by Abowei (2010) and 0.03 year $^{-1}$ in Lake of Guiers by Moreau et al. (1995). The shorter natural mortality rate may indicate that a shorter proportion die of natural cause than in Num River and Lake of Guiers.

The estimates of $\mathrm{E}$ of 0.14 indicates that the stock of $D$. rostratus population in Bandama River is not ove-exploited. This assumption is based on Gulland (1971), who stated that suitable yield is optimized when $F=M$, and when $\mathrm{E}>0.5$ the stock is generally supposed to be over fished.

From the probability of capture curve of $D$. rostratus, the length-atfirst capture (Lc) was $10.32 \mathrm{~cm}$. According to Berté et al. (2008), the size of first maturity of $D$. rostratus from Bandama River is $46.3 \mathrm{~cm}$ SL for females and $39.6 \mathrm{~cm}$ SL for males. This result shows that fishes were caught at smaller sizes before they had the chance to grow large enough and to breed to contribute substantially to stock biomass. Hence a fishery regulation of minimum escape gaps (mesh sizes) should be enforced in the D. rostratus fishery to ensure that small size fishes can escape from the traps when caught.

\section{Conclusion}

The present study shows that $D$. rostratus from the hydrosystem located between the hydroelectric dams of Kossou and Taabo have a better growth. Therefore, the exploitation rate indicates that the stock is lightly exploited.

\section{Acknowledgments}

Our thanks go to all the staff of the Hydrobiology Laboratory of Félix Houphouët-Boigny University (Côte d'Ivoire) for their invaluable help and advice. This study was financed thanks to the partnership between Hydrobiology Laboratory of Félix Houphouët-Boigny and the Project to Support Agricultural Research (PARA 2002). This study was also supported by the French cooperation. 


\section{References:}

Aboua, B.R.D., N’Zi, K.G., Kouamélan, E.P., Berté, S. \& Bamba, M. (2010). Organisation spatiale du peuplement de poissons dans le Bandama. International Journal of Biological and Chemical Sciences, 4, 1480-1493. Abowei, J.F.N. (2010). Some population parameters of Distichodus rostratus (Gunther, 1864) from the fresh Water reaches of lower Nun River, Niger Delta, Nigeria. Advance Journal of Food Science and Technology, 2, 84-90. Adams, P.B. (1980). Life history Pattern in marine fishes and their consequences for fisheries management. Fishery Bulletin, 78, 1-12.

Archibald, C.P., Fournier, D. \& Leaman, B.M. (1983). Reconstruction of stock history and development of rehabilitation strategies for Pacific ocean perch in Queen Charlotte Sound, Canada. North American Journal of Fisheries Management, 3, 283-294.

Balon, E.K. (1971). Age and growth of Hydrocynus vittatus Casteneau (1861) in Lake Kariba, Sinazongwe area. Fisheries Research Bulletin Zambia, 5, 89-93.

Berté, S., Kouamélan, E.P., Ouattara, N.I., Koné, T., Gooré Bi, G., N’Douba, V. \& Kouassi N.J. (2008). Cycle de reproduction et fécondité de Distichodus rostratus (Characiformes, Distichodontidae) dans un bassin ouest africain (fleuve Bandama, Côte d'Ivoire). Tropicultura, 26 (2), 104-107.

Booth, A.J. Foulis, A.J. \& Smale, M.J. (2011). Age validation, growth, mortality and demographic modelling of spotted gully shark (Triakis megalopterus) from the southeast coast of South Africa. Fishery Bulletin, 109, 101-112.

De Mérona, B., Hecht, T. \& Moreau, J. (1988). Croissance des poissons d'eau douce africains [Growth of African freshwater fishes]. In : Biologie et écologie des poissons d'eau douce africains (Lévêque C., Bruton M. N. \& Ssentongo G. W., eds). Paris: ORSTOM, 191-219.

Frisk, M.G., Miller, T.J. \& Fogarty, M.J. (2001). Estimation and analysis of biological parameters in elasmobranch fishes: a comparative life history study. Canadian Journal of Fisheries and Aquatic Sciences, 58, 969-981

Gayanilo, F.C., Jr Sparre, P. \& Pauly, D. (2002). The FAO-ICLARM Stock Assessment Tools II (FISAT II Ver. 1.2.1). FAO, Rome. Available at: http://www.fao.org/fi/statist/fisoft/fisat/

Gayanilo, F.C., Sparre, P. \& Pauly, D. (2005). FAO-ICLARM Stock Assessment tool II (FiSAT II) User's guide. FAO, Rome, 168 pp.

Girard, G., Sircoulon, J. \& Touchebeuf, P. (1971). Aperçu sur les régimes hydrologiques. In: Le milieu naturel en Côte d'Ivoire (Avenard J. M., Eldin M., Girard G., Sircoulon J., Touchebeuf P., Guillaumet J. L., Adjanohoun E. \& Perraud A., eds). Mémoire ORSTOM, 50, 109-155.

Gosse, P.J., Coenen, E.J. \& Teugels, G.G. (2003). Famille: Distichodontidae. In: Faune des poissons d'eaux douces et saumâtres de l'Afrique de l'Ouest, 
Paugy D., Lévêque C. \& Teugels G.G. (eds), IRD (Paris), MNHN (Paris) et MRAC (Tervuren), Collection Faune et Flore Tropicales, 1, 283-284.

Gulland, J. A. (1971). Fish Ressources of the Ocean. Fishing New Books Ltd for FAO, London, 255 p.

Iltis, A. \& Lévêque, C. (1982). Caractéristiques physico-chimiques des rivières de Côte d'Ivoire. Revue d'Hydrobiologie Tropicale, 15 (2), 115-130.

King, R.P. (1991). Some aspects of the reproductive strategy of Illisha africana (Block 1795) (Teleost, Clupudae) in Qua Iboe estuary, Nigeria. Cybium, 15(3), 239-251.

King, R.P. (2007). Fisheries biology \& assessment and management. Fishing news press, 340pp.

Koné, N., Kraidy, A.L.B., Boguhé, G.F.H., Berté, S., Bamba M. \& Kouamélan, E.P. (2014). Length-weight relationship and population parameters of Pellonula leonensis Boulenger 1916 (Clupeidae) in man-made Lake Taabo (Bandama basin; Côte d'Ivoire). International journal of Biosciences, 5 (4), 149-158.

Lévêque, C., Dejoux, C. \& Iltis, A. (1983). Limnologie du fleuve Bandama, Côte d'Ivoire. Hydrobiologia, 100, 113-141.

Moreau, J. \& Cuende, F.X. (1991). On improving the resolution of the recruitment patterns of fishes. ICLARM Fishbyte. 9, 45-46.

Moreau, J., Palomares, M.L.D, Torres, F.S.B, Jr \& Pauly, D. (1995). Atlas démographique des populations de poissons d'eau douce d'Afrique. ICLARM Rapp. Tech. 45, 140 p

Pauly, D. (1979). Theory and management of tropical multispecies stocks: a review with emphasis on the Southeast Asian demersal fisheries. Studies Review. 35 p.

Pauly, D. (1980). A selection of simple methods for the assessment of tropical fish stocks. FAO Fisheries Circular. 729 p.

Pauly, D. (1983). Some simple methods for the assessment of tropical fish stocks. FAO Fisheries Technical Paper, 234. 52 p.

Roff, D.A. (1983). An allocation model of growth and reproduction in fish. Canadian Journal of Fisheries and Aquatic Sciences, 40, 1395-1404.

Sparre, P. \& Venema, S.C. (1998). Introduction to tropical fish stock assessment. FAO Fisheries technical paper, Roma, 450 pp.

Tah, L., Joanny, T.G., N’Douba, V., Kouassi, N.J. \& Moreau, J. (2010). Preliminary estimates of the population parameters of major fish species in Lake Ayamé I (Bia basin; Côte d'Ivoire). Journal of Applied Ichthyology, 26, 57-63. 